\title{
THE EFFORTS TO IMPROVE LEARNING OUTCOMES ON LINEAR EQUATION SYSTEMS THREE VARIABLES BY USING POWER POINT MEDIA
}

\author{
Niki Ari Afgani \\ IKIP Siliwangi, Cimahi \\ rafanrausanfikri@gmail.com \\ Received: Jul 18 ${ }^{\text {th }}$, 2018; Accepted: Sep 13 ${ }^{\text {th }}, 2018$
}

\begin{abstract}
In Learning System of Three Variable Linear Equation System, class X of Integrated High School Ar-Risalah still many under KKM (KKM 60). Therefore, it is necessary an effort to improve the learning outcomes of Mathematics is through the media power point. This study aims to determine the improvement of learning outcomes of students class X IPA of Integrated High School Ar-Risalah academic of year 2017/2018 on the subject of SPLTV through power point media. The subjects of the study were the students class X IPA of Integrated high school Ar-Risalah of 22 students, a Mathematics teacher and 4 observers. Data collected included student learning outcomes, teacher observation results, student observation results. This research is a Classroom Action Research conducted in three cycles. The average value of test results cycle II, 53.18 increased by 30.49 compared to the average value of the results of the test cycle I, namely 22.69. And the average value of the third cycle test results that is 70.80 increased by 17.62 compared to the average value of the second cycle test results. In conclusion, that the result of the study, the students of Integrated High School Ar-Risalah on SPLTV can be improved through power point media.
\end{abstract}

Keywords: Learning outcomes, Media power point

\begin{abstract}
Abstrak
Dalam pembelajaran Sistem Sistem Persamaan Linear Tiga Variabel, siswa kelas X IPA SMA Terpadu Ar-Risalah masih banyak yang di bawah KKM (KKM 60). Oleh karena itu perlu suatu upaya untuk meningkatkan hasil belajar Matematika tersebut yaitu melalui media power point. Penelitian ini bertujuan untuk mengetahui peningkatan hasil belajar siswa kelas X IPA SMA Terpadu Ar-Risalah tahun pelajaran 2017/2018 pada materi pokok SPLTV melalui media power point. Subyek penelitian adalah siswa kelas X IPA SMA Terpadu Ar-Risalah jumlah 22 anak, seorang guru Matematika dan 4 orang pengamat. Data yang dikumpulkan meliputi hasil belajar siswa, hasil observasi guru, hasil observasi siswa. Penelitian ini merupakan Penelitian Tindakan Kelas (PTK) yang dilaksanakan dalam tiga siklus. Nilai rata-rata hasil tes siklus II, yaitu 53,18 meningkat sebesar 30,49 dibanding nilai rata-rata hasil tes siklus I, yaitu 22,69. Dan nilai rata-rata hasil tes siklus III yaitu 70,80 meningkat sebesar 17,62 dibanding nilai rata-rata hasil tes siklus ke II. Disimpulkan bahwa hasil belajar siswa kelas X IPA SMA Terpadu Ar-Risalah pada materi Sistem Persamaan Linear Tiga Variabel (SPLTV) dapat ditingkatkan melalui media power point.
\end{abstract}

Kata Kunci: Hasil belajar, Media power point

How to Cite Afgani, Niki Ari (2018). The Efforts To Improve Learning Outcomes On Linear Equation Systems Three Variables By Using Power Point Media. JIML, 1 (3), 225-232.

\section{INTRODUCTION}

In learning Mathematics most students consider mathematics is a difficult subject so that every time there is a Math lesson they are generally afraid, consequently difficult for students 
to focus of Mathematics material during teaching and learning activities. In line with the opinion of Merdian, A., Sari, V. T. A. dan Sugandi (2018) say that the reality in the field there are still many students who find it difficult to accept mathematics learning when the process of mathematics learning takes place. The subject of SPLTV that is now given in the first semester of $\mathrm{X}$ class is one of the materials which is often presented in the form of story matter. So almost every time to get to this material, many students not understand. As a result, the students are not able to solve the problems. In fact, when a test (repetition) on this material is held, many students get unsatisfied results. it means, that test score of the students is much under 60 (60 is the complete threshold for SPLTV subject matter). Therefore, researchers and colleagues of other mathematics teachers collaborate try to find the right way to overcome the problems that exist. Researchers also tried to use the media power point in learning activities, which will be expected to improve student learning outcomes, especially in solving the problems on the subject matter of Three Variable Linear Equations System. The purpose of this study is to know and analyze the improvement of learning outcomes of students class X IPA of Integrated High School Ar-Risalah for academic of year 2017/2018 in solving the problems on the subject matter of SPLTV by using power point media. The result of this TOD is expected to provide benefits are for students, teachers and schools especially in learning Mathematics. The benefits of this study are, increase motivation, confidence in solve the problems. Train students to active in learning activities, discussions and appreciate the other opinions. Improving students ability to understand and solve the story question and can improve students achievement as expected.

Learning outcomes are the most important part of learning. Sudjana \& Rivai (2007) defines students' learning outcomes as essentially behavioral changes as learning outcomes in a broader sense encompassing cognitive, affective, and psychomotor fields. Dimyati \& Mudjiono (2009) also mentions, that learning outcomes are the result of an interaction of learning and teaching. From the teacher side, the teaching act ends with the evaluation process of learning outcomes. From the student side, the learning outcome is the end of teaching from the summit of the learning process. It was concluded that learning outcomes were the abilities students had after receiving their learning experience. These abilities are include the cognitive, affective, and psychomotor aspects. Learning outcomes can be seen through evaluation activities that aim to obtain evidence data that will be show the level of ability of students in achieving learning objectives.

Microsoft PowerPoint is software used to design presentation materials in the form of slides. According to Susilana, PowerPoint is a presentation application program in computer. With the software, people can easily create a professional presentation form where the presentation can be used as a learning material (Understanding Microsoft PowerPoint: Function, Advantages \& Disadvantages, no date). With Media Power Point is expected all material presented by the teacher can be accepted by the students. Media Powerpoint has Power Point advantages that one feature provides the ability to create presentations that include music that plays entire presentations or sound effects for specific slides.

\section{METHOD}

This research used a descriptive method. Descriptive method is a procedure of problemsolving that is investigated by describing the state of the subject or object of research at the present, based on facts. The form of research used is Class Action Research (PTK), research conducted on a class to know the effect of action applied to a research subject in the class. The implementation in this research is Collaborative. Classroom Action Research should be done by teachers as researchers in collaboration with students, peers and/or Principals. 
This study was conducted from $15^{\text {th }}$ November 2017 to $29^{\text {th }}$ November 2017 in the odd semester of the academic year 2017-2018 in Senior high school Ar-Risalah Ciamis . The subject of this research is the students of class X IPA with 22 students, consisting of 8 men and 14 woman.

The tool is used to measure the ability of teachers and students in the learning process. The instruments used are (1) Observation sheets, teacher's observation sheets are used to see if the teacher's steps in teaching are in accordance with the lesson steps in the lesson plan and (2) the learning result test, the test is the method used or the procedure taken in the framework of measurement and assessment in the field of education, which provides the task and a series of tasks assigned by the teacher .so that, it can produce values that symbolize the behavior, learning outcomes or achievement learners. Data obtained from this research that comes from the test cycle I, the test cycle II and test cycle III. All data is processed using microsoft excel by calculating the average and see the average ratio of each cycle.

\section{RESULTS AND DISCUSSION Results}

Table 1. Recapitulation of Learning Implementation Assessment Results

\begin{tabular}{|c|c|c|c|c|}
\hline \multirow[b]{2}{*}{ No } & \multirow{2}{*}{ Rated aspect } & \multicolumn{3}{|c|}{ Score } \\
\hline & & Cycle & Cycle & Cycle \\
\hline 1 & Pre- Activity & & & \\
\hline & a. Preparing learners & 3 & 4 & 4 \\
\hline & b. Preparing aperseption & 2 & 3 & 4 \\
\hline & c. Describes the objectives to be achieved & 3 & 3 & 4 \\
\hline & $\begin{array}{l}\text { d. Delivering material coverage and explanation of activity } \\
\text { description in accordance with syllabus / instructional } \\
\text { materials }\end{array}$ & 2 & 2 & 3 \\
\hline & e. Teacher appearance & 4 & 4 & 4 \\
\hline 2 & Whilst Activity & & & \\
\hline & $\begin{array}{l}\text { a. Involving the students in searching information and } \\
\text { learning from of various sources }\end{array}$ & 2 & 2 & 3 \\
\hline & $\begin{array}{l}\text { b. Using a variety of learning approaches, learning media and } \\
\text { learning resources }\end{array}$ & 3 & 3 & 4 \\
\hline & $\begin{array}{l}\text { c. Facilitating interaction between students and students with } \\
\text { teachers, environment and other learning resources }\end{array}$ & 2 & 3 & 3 \\
\hline & $\begin{array}{l}\text { d. Involving the students to active in various learning } \\
\text { activities }\end{array}$ & 2 & 3 & 4 \\
\hline & $\begin{array}{l}\text { e. Guiding students to read and write diverse through } \\
\text { meaningful tasks }\end{array}$ & 2 & 2 & 3 \\
\hline & $\begin{array}{l}\text { f. Facilitating students through the assignment of discussion } \\
\text { assignments and others to elicit new ideas, both oral and } \\
\text { written }\end{array}$ & 3 & 3 & 4 \\
\hline & $\begin{array}{l}\text { g. Giving the opportunity to think, analyze problem solving, } \\
\text { and act without fear }\end{array}$ & 3 & 3 & 3 \\
\hline & $\begin{array}{l}\text { h. Facilitating students in cooperative and collaborative } \\
\text { learning }\end{array}$ & 2 & 3 & 4 \\
\hline
\end{tabular}


228 Afgani, The Efforts To Improve Learning Outcomes On Linear Equation Systems Three Variables By Using Power Point Media.

\begin{tabular}{|c|c|c|c|c|}
\hline & $\begin{array}{l}\text { i. Facilitating students to compete in a healthy way to } \\
\text { improve learning outcomes }\end{array}$ & 2 & 3 & 3 \\
\hline & $\begin{array}{l}\text { j. Facilitating students to make exploration reports conducted } \\
\text { both orally and in writing individually or in groups }\end{array}$ & 2 & 3 & 4 \\
\hline & $\begin{array}{l}\text { k. Facilitate students to present their work individually or in } \\
\text { groups }\end{array}$ & 3 & 3 & 4 \\
\hline & $\begin{array}{l}\text { 1. Provide positive feedback and reinforcement in the form of } \\
\text { oral, written, gestures, or gifts to the success of students }\end{array}$ & 2 & 3 & 4 \\
\hline & $\begin{array}{l}\text { m. Provide confirmation of students' exploration and } \\
\text { elaboration results through various sources }\end{array}$ & 3 & 4 & 4 \\
\hline & $\begin{array}{l}\text { n. Facilitating students to reflect to get the learning experience } \\
\text { that has been done }\end{array}$ & 3 & 3 & 4 \\
\hline & $\begin{array}{l}\text { o. Serves as a resource and facilitator in answering questions } \\
\text { of students who feels difficulties }\end{array}$ & 4 & 4 & 4 \\
\hline & $\begin{array}{l}\text { p. Helping the student problems in checking exploration } \\
\text { results }\end{array}$ & 3 & 4 & 4 \\
\hline & $\begin{array}{l}\text { q. giving motivation to students who are not active and giving } \\
\text { information to more explore their ability. }\end{array}$ & 2 & 3 & 4 \\
\hline 3 & Post Activity & & & \\
\hline & a. Make a summary / conclusion & 3 & 4 & 4 \\
\hline & $\begin{array}{l}\text { b. Conduct assessment and or reflection on learning activities } \\
\text { that have been done }\end{array}$ & 2 & 3 & 4 \\
\hline & c. Provide feedback on the learning process & 2 & 2 & 3 \\
\hline & d. Provide structured tasks and unstructured tasks & 2 & 2 & 3 \\
\hline & e. Delivering a lesson plan at the next meeting & 3 & 4 & 4 \\
\hline & Total score & 69 & 83 & 100 \\
\hline & Value & 2,56 & 3,07 & 3,70 \\
\hline
\end{tabular}

Teachers have the ability and skill in carrying out the learning steps by using the power point media in mathematics of learning Three Variable Linear Equation System (SPLTV) in class X IPA of Integrated High School Ar-Risalah Ciamis from average cycle score 1 = 2,56; cycle $2=3.07$; cycle $3=3.70$. There appears to be a significant increase the ability of teachers in implementing learning activities in accordance with the RPP that has been made.

Table 2. Recapitulation of students learning Results

\begin{tabular}{ccccc}
\hline \multirow{2}{*}{ No } & Subject & Value & & \\
\cline { 2 - 5 } & & cycle $\mathbf{1}$ & cycle 2 & cycle 3 \\
\hline 1 & S-1 & 30 & 33 & 40 \\
\hline 2 & S-2 & 6 & 20 & 48 \\
\hline 3 & S-3 & 20 & 40 & 83 \\
\hline 4 & S-4 & 7 & 17 & 50 \\
\hline 5 & S-5 & 12 & 54 & 77 \\
\hline 6 & S-6 & 50 & 87 & 93 \\
\hline 7 & S-7 & 11 & 50 & 67 \\
\hline 8 & S-8 & 15 & 57 & 87 \\
\hline 9 & S-9 & 15 & 38 & 67 \\
\hline 10 & S-10 & 22 & 80 & 83 \\
\hline 11 & S-11 & 33 & 33 & 47 \\
\hline
\end{tabular}




\begin{tabular}{ccccc}
12 & S-12 & 40 & 63 & 87 \\
\hline 13 & S-13 & 25 & 70 & 87 \\
\hline 14 & S-14 & 29 & 67 & 77 \\
\hline 15 & S-15 & 21 & 90 & 93 \\
\hline 16 & S-16 & 21 & 50 & 67 \\
\hline 17 & S-17 & 53 & 57 & 62 \\
\hline 18 & S-18 & 0 & 30 & 50 \\
\hline 19 & S-19 & 6 & 47 & 60 \\
\hline 20 & S-20 & 16 & 57 & 60 \\
\hline 21 & S-21 & 43 & 51 & 87 \\
\hline 22 & S-22 & 25 & 80 & 87 \\
\hline Largest & $\mathbf{5 3}$ & $\mathbf{9 0}$ & $\mathbf{9 3}$ \\
\hline Smallest & $\mathbf{0}$ & $\mathbf{1 7}$ & $\mathbf{4 0}$ \\
\hline Average & $\mathbf{2 2 , 6 9}$ & $\mathbf{5 3 , 1 8}$ & $\mathbf{7 0 , 8 0}$ \\
\hline
\end{tabular}

\section{Discussion}

\section{Cycle I}

\section{Planning}

In this part, is the making of learning implementation plan (RPP) based on the syllabus used as the research reference. The RPP made for cycle I consists of 1 encounter on the material "Three Variable Linear Equations System (SPLTV)" by using power point media and has indicators: (1) Finding the concept of a linear equation system of three variables; (2) Creating a mathematical model of a system of linear equations of three variables of the contextual problem.

Then the researcher makes an observation sheet to teachers and students (observed aspects are based on lessons learned in the lesson plan), prepares a reflection journal sheet and designs an evaluation tool for the first cycle test. Another preparation is to further strengthen the teacher's knowledge and understanding of the implementation of the lesson using power point media.

\section{Implementation of Action (Do)}

This activitiy is done by the teacher of mathematics class X IPA of Integrated High School Ar-Risalah Ciamis. meanwhile, researchers act as observers (observer). The first cycle of learning is carried out in a single meeting. After the presentation of this first class, teachers and researchers discuss some of the shortcomings that occur in learning activities. From the results of this discussion, the teacher is willing to correct the deficiencies at the next meeting.

\section{Evaluation (See)}

After one meeting, the evaluation is conducted with the label of cycle I. This activity is conducted to know the extent of student learning outcomes in cycle 1 . The test results show that student learning outcomes are still very low. Can be seen from the average value of the test cycle I is 22.69 .

\section{Cycle II}

Planning (Plan)

Based on the results of observation and evaluation on the action of cycle I, the researchers and the teacher planning the action of cycle II, so that the weaknesses that occur in the 
implementation of the action cycle I can be improved and achieve maximum results. The things that must be improved by the teachers on the implementation of the second cycle are as follows: (1) The teacher should be explain the material and describing the activity in according to syllabus / teaching materials; (2) Teachers should be involve students in searching information and learning from various sources; (3) The teacher should be involve the students actively in various learning activities; (4) Teachers should be guide the students to reading and writing any other various through meaningful tasks; (5) The teacher should be make an assessment and / or reflection on the learning activities that have been done; and (6) The teacher should be provide feedback on the learning process.In this stage is the making of lesson plan plan (RPP) based on the syllabus used as the research reference. The RPP made for cycle II consists of 1 meeting. Then the researcher makes an observation sheet for the teachers and students (observed aspects are based on learning steps in RPP), preparing the reflection journal sheet and designing evaluation tools for the second cycle test. Another preparation is to further strengthen the knowledge and understanding of teachers on the implementation of learning by using media power point.

\section{Implementation of Action (Do)}

This activity is done by the teacher of mathematics class X IPA of Integrated High School ArRisalah Ciamis, meanwhile, researchers act as observers (observer). The second cycle learning action was conducted in one meeting. After this second class presentation, the researcher assesses the teacher is good enough in directing the students to ask and respond. Teachers provide some examples and work with students. Hopeful, that students are able to understand the material. The teacher also asks the students to conclude, solve the problems in LK, present the group work, clarify the knowledge acquired and predict the difficult questions of some of the problems previously given.

At the end of the learning cycle II, teachers together with students summarize the results of discussion and reflection. Furthermore, teachers give homework to be done for students to understand and solve the problem of mathematics students become better. Teacher ends the lesson with advice and salam for close the teaching and learning activities. Observation sheets for teachers and students are still used by researchers to observe the learning activities that they have been carried out.

\section{Evaluation (See)}

In this cycle II, learning is done as much as one meeting. Evaluation is held with the test cycle II. This activity is done to know the extent of student learning outcomes in cycle II. The average value of the second cycle test is 53.18. This shows that the average score of students' learning achievement of XA IPA SMA Arjaman Ar-Risalah Ciamis on the material has been an increase of 30.49 from cycle I of 22.69. In addition, the results of cycle II test score is also important to know the students' learning outcomes by using the media power point for each meeting conducted.

\section{Cycle III}

\section{Planning (Plan)}

Based on the results of observation and evaluation on the action cycle II, the researchers along with the teacher plan action cycle III, so that the weaknesses that occur in the implementation of action cycle II can be improved and achieve maximum results. Things that should be improved by teachers on the implementation of action cycle III are as follows: (1) Teachers should be able to involve students in seeking information and learning from various sources; (2) Teachers should be able to guide students reading and writing diverse through meaningful tasks, and; (3) Teachers should be able to provide feedback on the learning process. 
The things that are done at this stage is the making of learning implementation plan (RPP) based on the syllabus used as the research reference. The RPP made for cycle III consists of 1 meeting. Then the researcher makes an observation sheet addressed to teachers and students (observed aspects are based on learning steps in the lesson plan), prepares a reflection journal sheet and designs evaluation tools for cycle III tests. Another preparation is to further strengthen the knowledge and understanding of teachers on the implementation of learning by using power point

\section{Implementation of Action (Do)}

This activities is done by the teacher of mathematics class X IPA of Integrated High School Ar-Risalah Ciamis, Meanwwhile, researchers still act as observers (observer). The action of learning cycle III is conducted in one meeting. After this second class presentation, the researcher assesses the teacher has been very good in directing the students to ask and respond. Teachers provide some examples and work with students in the hope that students are able to understand the material. The teacher also asks the students to conclude, solve the problems in LK, present the group work, clarify the knowledge acquired and predict the difficult questions of some of the problems previously given.

At the end of the learning cycle III, teachers together with students summarize the results of discussion and reflection. Furthermore, teachers give homework to be done for students to understand and solve the problem of mathematics students become better. Teacher ends the lesson with advice and salam closes. Observation sheets for teachers and students are still used by researchers to observe the learning process that lasts from start to finish.

\section{Evaluation (See)}

In this cycle III, learning is done as much as one meeting. Evaluation is held with the label cycle III. This activity is done to know the extent of student learning outcomes after learning by using media power point. The average value of the third cycle test is 70.80 . This shows that the average value of the students' learning outcomes XA IPA SMA Integrated Ar-Risalah Ciamis to the matter there is a further increase of 17.62 from cycle II. In addition, the results of the value of the test cycle III is also important to know the learning outcomes by using the media power point for each meeting conducted.

\section{Reflection}

Reflection on cycle III, is showing encouraging results, both for teachers and for researchers. The results of observations conducted by researchers showed that the use of power point media applied in class X IPA Integrated High School Ar-Risalah Ciamis provide excellent results. Thus, the hypothesis of this study action has been achieved that there is an increase in the results of students' learning grade X IPA Integrated High School Ar-Risalah Ciamis on Linear Three-Variable Equation System (SPLTV) by using power point media.

\section{CONCLUSION}

Based on the results of the analysis and discussion, it can be concluded that the learning outcomes of students of class X IPA SMA Integrated Ar-Risalah Ciamis on Linear ThreeVariable Equation System (SPLTV) can be improved through learning by using power point media. 
232 Afgani, The Efforts To Improve Learning Outcomes On Linear Equation Systems Three Variables By Using Power Point Media.

\section{ACKNOWLEDGMENTS}

Alhamdulillahi rabil 'alamin, the researcher expresses his highest gratitude to Allah subhanahu wa ta'ala for blessing, love, opportunity, health, and mercy to complete this article. I would like to thank everybody who was important to the successful realization of this article. This article is far from perfect, but it is expected that it will be useful not only for the researcher, but also for the readers. For this reason, constructive thoughtfull suggestion and critics are welcomed.

\section{REFERENCES}

Dimyati, \& Mudjiono. (2009). Konsentrasi Belajar. Kesehatan Mental.

Merdian, A., Sari, V. T. A. dan Sugandi, A. I. (2018). Analisis Kemampuan Komunikasi Matematis dan Keaktifan Siswa SMA dengan Pendekatan Problem Posing. SOSIOHUMANIORA: Jurnal LP3M - UST Yogyakarta, 4(1), 45-50. https://doi.org/10.30738/sosio.v4i1.2279

Sudjana, N., \& Rivai, A. (2007). Media Pengajaran. Sinar Baru Algensindo. https://doi.org/10.5194/hess-11-1609-2007 